JOURNAL: EXPERT OPINION ON BIOLOGICAL THERAPY

\title{
BIOLOGICS FOR TREATING AXIAL SPONDYLOARTHRITIS
}

Alexis Jones ${ }^{1}$, Coziana Ciurtin ${ }^{2}$, Mediola Ismajli ${ }^{3}$, Maria Leandro ${ }^{4}$, Raj Sengupta ${ }^{5}$, Pedro M Machado $^{6, *}$

${ }^{1}$ Senior Clinical Research Fellow

University College London Hospitals NHS Foundation Trust - Rheumatology Department

London, London NW1 2PG

United Kingdom of Great Britain and Northern Ireland

${ }^{2}$ Principal Research Associate and Consultant Rheumatologist

University College London Hospitals NHS Foundation Trust

London, London NW1 2PG

United Kingdom of Great Britain and Northern Ireland

${ }^{3}$ Consultant Rheumatologist

Chelsea and Westminster Hospital NHS Foundation Trust - Rheumatology Department

London, London SW10 9NH

United Kingdom of Great Britain and Northern Ireland

${ }^{4}$ Consultant Rheumatologist

University College London Hospitals NHS Foundation Trust

London, London NW1 2PG

United Kingdom of Great Britain and Northern Ireland

${ }^{5}$ Consultant Rheumatologist

Royal National Hospital For Rheumatic Diseases NHS Foundation Trust

Bath, Bath and North East Somer BA1 1RL

United Kingdom of Great Britain and Northern Ireland

${ }^{6}$ NIHR Post-Doctoral Fellow and Honorary Consultant Rheumatologist

University College London

1st Floor, Russell Square House 10-12 Russell Square, London WC1B 5EH

United Kingdom of Great Britain and Northern Ireland

*Corresponding author : Pedro Machado ; Email: p.machado@ucl.ac.uk 


\begin{abstract}
Introduction: Spondyloarthritis ( $\mathrm{SpA}$ ) encompasses a heterogeneous group of diseases sharing genetic, immunological, clinical and imaging features. Axial spondyloarthritis (axSpA) refers to a subgroup characterised predominately by inflammation of the axial skeleton with subsequent symptoms of chronic (often inflammatory) back pain and sacroiliitis. There is a strong association with the major histocompatibility complex (MHC) class I allele human leukocyte antigen (HLA) B27. In the last decade, there has been significant progress in earlier detection of the disease and the molecular mechanisms involved in its pathogenesis. The subsequent introduction of anti-tumour necrosis factor (TNF) has revolutionised the treatment of patients with axSpA.

Areas covered: In this article, we review the current biologic therapies for axSpA, the emergence of biosimilars, predictors of response, primary and secondary failure and new biologics on the horizon.

Expert opinion: There have been significant advances in the treatment of axSpA. Beyond the clear efficacy of anti-TNF inhibition, IL-17 offers an alternative therapeutic target and there is promise from inhibition of the IL-17/IL-23 pathway and small molecules, such as Janus kinase (JAK) inhibitors. Biosimilars have offered greater affordability and choice within this increasingly growing field of therapeutics.
\end{abstract}

Keywords: Spondyloarthritis, ankylosing spondylitis, biologics, anti-TNF, anti-IL17, biosimilars. 


\section{INTRODUCTION}

Spondyloarthritis $(\mathrm{SpA})$ encompasses a group of immune-mediated inflammatory diseases that classically include ankylosing spondylitis (AS), psoriatic arthritis (PsA), reactive arthritis, arthritis associated with inflammatory bowel disease and a subgroup of juvenile idiopathic arthritis (JIA). Clinically, these conditions are characterised by axial inflammation, peripheral arthritis, enthesitis, dactylitis and extra-articular features such as psoriasis, uveitis and inflammatory bowel disease. They share similar pathogenic mechanisms and are strongly associated with the major histocompatibility complex (MHC) class I allele human leukocyte antigen (HLA) B27 (1). The disease typically affects young men and women in their second and third decades of life with a prevalence ranging from $0.2 \%$ in South-East Asia to $1.6 \%$ in Northern Arctic communities (2).

The Assessment of Spondyloarthritis International Society (ASAS) simplified the classification of $\mathrm{SpA}$ by dividing the group into axial(3) and peripheral $\mathrm{SpA}(4)$. Peripheral $\mathrm{SpA}(\mathrm{pSpA})$ refers to disease with predominantly peripheral features of enthesitis, arthritis or dactylitis; and axial SpA (axSpA) encompasses patients with inflammation of the axial skeleton. Axial SpA includes patients with ankylosing spondylitis (AS) with established sacroiliitis on X-ray. It also includes a further subgroup called non radiographic axial SpA (nr-axSpA). This subgroup was created owing to the recognition of early axial disease on MRI. Typically, these patients have symptoms of chronic (often inflammatory) back pain with evidence of (active/acute) sacroiliitis on MRI in the absence of definite $\mathrm{X}$-ray changes; in order to fulfil classification criteria, $\mathrm{nr}$-axSpA patients must also have at least one other SpA feature: this includes inflammatory back pain, arthritis, enthesitis of the heel, uveitis, dactylitis, psoriasis, inflammatory bowel disease, good response to non-steroidal anti-inflammatories (NSAIDs), family history for SpA, HLA B27 or elevated CRP. HLA-B27 positive patients who have at least 2 additional SpA features can also fulfil ASAS classification criteria for axSpA, even in the absence of imaging features (clinical arm of the classification criteria). ASAS classification criteria are only applicable to patients with an onset of chronic back pain before the age of 45 years. Of note, the ASAS classification criteria are not meant to be used as diagnostic criteria; classification criteria are primarily intended to create well-defined homogeneous groups of patients with a classical disease picture. The conceptual model representing the entire spectrum of axSpA is presented in Figure 1.

In this article, we shall review the treatment algorithm for axSpA with a primary focus on the different biologic therapies available and the evidence for their use. We shall discuss predictors of response to biologics and causes of primary and secondary failure. Finally, we shall examine novel therapeutic targets and potential biologics on the horizon. 
Figure 1. The spectrum of axial spondyloarthritis (axSpA). MRI positivity (active sacroiliitis/spondylitis based on the presence of typical bone marrow oedema lesions on MRI*) may fluctuate over time. Non-radiographic axSpA is not necessarily a pre-radiographic form of the disease, since many patients do not progress to radiographic axSpA. Spinal X-ray lesions are syndesmophytes, bridging of the vertebral bodies and ankylosis of the facet joints. *Currently, only MRI positivity of the sacroiliac joints is included as one of the items of the ASAS classification criteria for axSpA.

\section{Axial SpA (axSpA)}

\section{Non-radiographic axSpA $(\mathrm{nr}-\mathrm{axSpA})$}

MRI -ve sacroilitis/spondylitis
MRI +ve

sacroilitis/spondylitis

\section{Radiographic axSpA}

$(\mathrm{r}-\mathrm{axSpA})$
X-ray +ve sacroilifitis

(with or without spinal $\mathrm{X}$-ray lesions)
Spinal X-ray lesions without X-ray +ve sacroilititis 


\section{MANAGEMENT OF AXIAL SPONDYLOARTHRITIS}

Prior to the introduction of biologic therapies, treatment of axSpA was limited to non-steroidal antiinflammatory drugs (NSAIDs) and physical therapy. Both have demonstrated efficacy in improving symptoms of inflammatory back pain and NSAIDs can also be effective in reducing the level of acute phase reactants such as C-reactive protein (CRP) (5). Unfortunately, axial and entheseal manifestations of SpA do not respond well to conventional synthetic disease modifying anti-rheumatic drugs (csDMARDs).

There is some controversy regarding NSAIDs and radiographic progression of axial disease. Wanders et al showed that when taken continuously as a daily dose over 2 years, Celecoxib was able to reduce radiographic progression of spinal disease compared with an on-demand treatment schedule (6). However, results from a more recent randomised multicentre trial (ENRADAS) in AS patients showed that continuous Diclofenac over 2 years did not reduce radiographic progression compared to on-demand treatment (7). A sub analysis of the Wanders study showed that patients with elevated acute phase reactants seemed to benefit most from continuous treatment with Celecoxib (8). Another study in patients with AS over 2 years, demonstrated slowing of new bone formation in the spine of patients with a high NSAID intake compared with patients with low NSAID intake. This protective effect was nearly exclusively seen in patients with elevated CRP levels and the presence of syndesmophytes at baseline (9).

Seminal studies for the use of biologics in axSpA are listed in Table 1. There are currently five licensed anti-TNF drugs for the indication of axSpA: Adalimumab, Certolizumab, Etanercept, Golimumab and Infliximab (in alphabetical order). These therapies can be used as monotherapy, without the need to combine them with csDMARDs. All, except Infliximab, have European Medicines Agency (EMA) approval for both radiographic and non-radiographic axSpA. Biosimilars of Infliximab, Etanercept and Adalimumab have also been approved by the EMA. The IL-17 inhibitor, Secukinumab, has also been approved by the EMA but only for axSpA patients with radiographic sacroiliitis. The European label for nr-axSpA is restricted to patients with objective signs of inflammation by elevated CRP and/or MRI inflammation. The US Food and Drug Administration (FDA) has approved Adalimumab, Etanercept, Certolizumab, Golimumab and Infliximab for the treatment of AS. However, in October 2013, the FDA rejected Adalimumab and Certolizumab for treatment of nr-axSpA. Among other reasons, the FDA's primary concern was regarding the specificity of the ASAS axSpA classification criteria when erroneously used for diagnostic purposes. In the UK, Infliximab was licensed for the treatment of AS in 2008. Subsequently, the other four TNF inhibitors were introduced for the treatment of AS. In December 2016, the IL-17 inhibitor, Secukinumab, was approved by the National Institute for Clinical Excellence (NICE) for treatment of AS. Adalimumab, Etanercept, Certolizumab and Golimumab (health technology appraisal for Golimumab published in January 2018) are all licensed for the treatment of nr-axSpA.

The safety of anti-TNF therapies in axSpA is comparable to other inflammatory joint diseases such as rheumatoid arthritis (RA). There is little evidence to suggest that safety issues differ hugely with different disease groups. More recent trials have not suggested any new or unkown safety signals for anti-TNF therapies (10).

\section{$\underline{\text { 2.1 Criteria for commencing biologic therapy }}$}

The ASAS-EULAR (2016 update) recommend commencing anti-TNF therapy in those with high disease activity defined by either a Bath Ankylosing Spondylitis Disease Activity Index (BASDAI) $\geq 4$ or an Ankylosing Spondylitis Disease Activity Score (ASDAS) $\geq 2.1$ after two different NSAIDs for at least 4 weeks in total (11). The American College of Rheumatology/Spondylitis Association of America/Spondyloarthritis Research and Treatment Network recommend anti-TNF drugs in patients with AS when activity persists despite NSAID treatment. No particular anti-TNF is preferred except in patients with concomitant inflammatory bowel disease or recurrent iritis, in whom anti-TNF monoclonal 
antibodies should be used. In patients with active nr-axSpA despite treatment, conditional recommendations have been made for treatment with anti-TNF (12). The British Society of Rheumatology (BSR) and British Health Professionals in Rheumatology (BHPR) guidelines(13) and NICE guidelines (14) define high disease activity as a BASDAI and spinal pain visual analogue scale (VAS) score $\geq 4$. According to the BSR, patients need to have failed two NSAIDs for at least two weeks each, unless contraindicated, and the BASDAI should be measured on two occasions at least 4 weeks apart.

\section{$\underline{\text { 2.2 Currently approved biologic therapies, including biosimilars }}$}

\subsubsection{Adalimumab}

Adalimumab is a fully human monoclonal antibody that binds with high affinity to TNF. The ATLAS trial demonstrated clear efficacy of Adalimumab in active AS over the 24-week study period. In this study $58.2 \%$ patients achieved a 20\% Assessment of Ankylosing Spondylitis (ASAS20) improvement in the adalimumab group compared to $20.6 \%$ in the placebo group by week 12 (15). The use of Adalimumab in nr-axSpA was demonstrated by the ABILITY-1 study. In this study, ASAS40 response rates in the adalimumab treated group were $36 \%$ compared to $15 \%$ in the placebo group at week $12(16)$. The longterm efficacy of adalimumab has been demonstrated in a 5 year follow-up study in patients with AS. In this study $70 \%$ of patients achieved ASAS40 (17).

\subsubsection{Certolizumab}

Certolizumab is a PEGylated Fc-free anti-TNF. A phase 3 double-blind, randomized study, evaluated the efficacy and safety of Certolizumab in patients with axSpA, including patients with AS and nr-axSpA. At week 12, ASAS20 response rates were significantly higher in the Certolizumab groups compared to placebo (57.7\% (200mg) and 63.6\% (400mg) vs 38.3\% (placebo), p $\leq 0.004)$. At week 24, patients in the certolizumab group showed significant differences in BASDAI, ASDAS, Bath Ankylosing Spondylitis Functional Index (BASFI), and Bath Ankylosing Spondylitis Metrology Index (BASMI) scores. The results of this trial demonstrated that certolizumab led to rapid improvements in clinical signs and symptoms in axSpA (18). The clinical efficacy of Certolizumab in axSpA has been demonstrated at 4year follow-up in patients with axSpA including AS and nr-axSpA (19). Sustained efficacy at the MRI level has been shown in a recently published 95 -week study (20).

\subsubsection{Etanercept}

Etanercept is a recombinant TNF receptor p75 Fc fusion protein that acts competitively to inhibit cell surface receptor binding of TNF. Its safety and sustained clinical response in AS was studied in 277 patients who had participated in a previous randomised, double blind, placebo controlled 24 week trial that continued in an open label extension study for a total of 2 years. In the Etanercept group, 74\% achieved an ASAS20 response after 96 weeks (21). Its efficacy in nr-axSpA was initially demonstrated in the ESTHER trial, where $50 \%$ of the patients $(\mathrm{n}=36)$ achieved remission in the etanercept group compared with $19 \%$ in the sulfasalazine group at week 48 (22). The long-term efficacy and safety of etanercept was demonstrated in a 7-year follow-up study of patients with AS, where $31 \%$ of patients were in ASAS partial remission, and $44 \%$ had ASDAS inactive disease (23). The EMBARK study was the pivotal study resulting in the market authorisation of Etanercept in $\mathrm{nr}-\mathrm{axSpA}(24)$. This study showed rapid, significant improvement in symptomatic disease activity, function, and systemic and skeletal inflammation over 12 weeks. Clinical and functional improvement was sustained over 24 weeks. 


\subsubsection{Infliximab}

Infliximab is a monoclonal chimeric human anti-TNF antibody that binds with high affinity to TNF. The efficacy of Infliximab was demonstrated in the ASSERT trial; a multicentre, randomised study, where $61.2 \%$ of AS patients in the Infliximab group were ASAS20 responders compared with $19.2 \%$ of patients in the placebo group (25). Persistent clinical efficacy and safety of infliximab was demonstrated after 8 years of follow-up in patients with active AS treated with Infliximab, where $24 \%$ of the patients were in partial remission $(\mathrm{n}=8)$ and $64 \%(\mathrm{n}=21)$ had low disease activity $(\mathrm{BASDAI}<3)(26)$.

\subsubsection{Golimumab}

Golimumab is a humanised monoclonal antibody to TNF. In the GO-RAISE study, Golimumab was proven to be effective and well tolerated in a large cohort of patients with AS. At 14 weeks, about $60 \%$ achieved ASAS20 response in the golimumab treated patients compared to $21.8 \%$ in the placebo group (27). Golimumab has also been shown to be effective in nr-axSpA in the GO-AHEAD 16-week study, where the primary endpoint (ASAS20 at week 16) was achieved in $71.1 \%$ in the golimumab group versus $40.0 \%$ in the placebo group(28).

\subsubsection{Secukinumab}

Secukinumab is a monoclonal antibody of the $\operatorname{IgG1/kappa~isotype~that~targets~interleukin-17.~It~has~}$ recently been licensed for treatment of AS in patients who have failed NSAIDs or anti-TNF. The MEASURE trials demonstrated safety and efficacy of Secukinumab in patients who were anti-TNF naive and those who had previously failed anti-TNF. In MEASURE 1 (371 patients), the ASAS20 response rates at week 16 were $61 \%, 60 \%$ and $29 \%$ for subcutaneous Secukinumab at doses of $150 \mathrm{mg}$ and $75 \mathrm{mg}$ and for placebo, respectively ( $\mathrm{p}<0.001)$. In MEASURE 2 (219 patients), the ASAS20 response rates were $61 \%, 41 \%$, and $28 \%$ for subcutaneous Secukinumab at doses of $150 \mathrm{mg}$ and $75 \mathrm{mg}$ and for placebo, respectively ( $<<0.001$ for the $150-\mathrm{mg}$ dose and $\mathrm{p}=0.10$ for the $75-\mathrm{mg}$ dose). There were also statistically significant improvements in the BASDAI 50 (the proportion of patients achieving a $50 \%$ improvement in BASDAI score) and in the change from baseline BASFI scores in the Secukinumab arms of the trials compared with placebo(29). An efficacy and safety RCT of Secukinumab in patients with nr-axSpA is ongoing (NCT02696031). 
Table 1. Seminal studies for the use of biologics in axSpA

\begin{tabular}{|c|c|c|c|c|c|c|c|}
\hline Outcome & Drug & Study & $\mathrm{N}$ patients & $\begin{array}{l}\text { Time point } \\
\text { (weeks) }\end{array}$ & $\begin{array}{l}\text { Response to } \\
\text { treatment (\%) }\end{array}$ & $\begin{array}{l}\text { Response to } \\
\text { placebo (\%) }\end{array}$ & NNT \\
\hline \multirow{6}{*}{ ASAS-20 } & Adalimumab & ATLAS(30) & 315 & 12 & 58.2 & 20.6 & 2.7 \\
\hline & Certolizumab (200mg) & RAPID-axSpA(18) & 122 & 24 & 67.7 & 33.3 & 2.9 \\
\hline & Etanercept & Davis et al(31) & 277 & 24 & 57 & & 2.9 \\
\hline & Infliximab & ASSERT(32) & 279 & 24 & 61.2 & 19.2 & 2.4 \\
\hline & Golimumab & GO-RAISE(33) & 216 & 14 & 58.2 & 20.6 & 2.7 \\
\hline & $\begin{array}{c}\text { Secukinumab } \\
\text { (150mg) }\end{array}$ & MEASURE 1(29) & 371 & 16 & & 29 & 3.1 \\
\hline \multirow{6}{*}{ ASAS-40 } & Adalimumab & ATLAS(30) & 315 & 12 & 39.4 & 13.1 & 3.8 \\
\hline & Certolizumab (200mg) & RAPID-axSpA(18) & 122 & 24 & 47.7 & 15.8 & 3.1 \\
\hline & Etanercept & SPINE(34) & 82 & 12 & 44.7 & 25.6 & 5.2 \\
\hline & Infliximab & ASSERT(32) & 279 & 24 & 47 & 12 & 2.9 \\
\hline & Golimumab & GO RAISE(33) & 24 & 54.3 & 15.4 & 15.4 & 2.6 \\
\hline & $\begin{array}{c}\text { Secukinumab } \\
\text { (150mg) }\end{array}$ & MEASURE 1(29) & & 16 & 43 & 13 & 3.3 \\
\hline Outcome & Drug & & $\mathrm{N}$ patient & Time point & $\begin{array}{c}\text { Response to } \\
\text { treatment }\end{array}$ & $\begin{array}{c}\text { Response to } \\
\text { placebo }\end{array}$ & NNT \\
\hline \multirow{6}{*}{ ASAS-20 } & Adalimumab & ABILITY-1(16) & 185 & 12 & 51.6 & 30.9 & 4.8 \\
\hline & Certolizumab & RADID-axSPA(18) & 96 & 24 & 65.2 & 24.0 & 2.4 \\
\hline & Etanercept & EMBARK(35) & 215 & 12 & 52.4 & 36.1 & 6.1 \\
\hline & Infliximab & - & - & - & - & - & - \\
\hline & Golimumab & GO-AHEAD(36) & 198 & 16 & 71.1 & 40.0 & 3.2 \\
\hline & Secukinumab & - & - & - & - & - & - \\
\hline \multirow{6}{*}{ ASAS-40 } & Adalimumab & ABILITY-1(16) & 185 & 12 & 36.3 & 14.9 & 4.7 \\
\hline & Certolizumab & RADID-axSPA(18) & 96 & 24 & 56.5 & 14.0 & 2.7 \\
\hline & Etanercept & EMBARK(35) & 215 & 12 & 33.3 & 14.8 & 5.4 \\
\hline & Infliximab & - & - & - & - & - & - \\
\hline & Golimumab & GO-AHEAD(36) & 198 & 16 & 56.7 & 23.0 & 3.0 \\
\hline & Secukinumab & - & - & - & - & - & - \\
\hline
\end{tabular}




\subsubsection{Biosimilars}

Biologics have revolutionized the treatment of axSpA. However, these drugs are expensive resulting in wide inequalities in their use. The emergence of biosimilars offers the promise of substantial savings relative to the reference medicinal product (RMP) enabling more patients to access biologic therapy. A biosimilar is defined by the World Health Organisation (WHO) as a biotherapeutic product that is similar in terms of quality, safety, and efficacy to an already licensed reference biotherapeutic product(37). It has been estimated that Germany, France and the UK each stand to save between $€ 2.3$ billion and $€ 11.7$ billion between 2007 and 2020 in response to the introduction of biosimilars (38).

Biosimilars of four RMPs, Adalimumab, Etanercept, Infliximab and Rituximab, have now been approved by the European Medicines Agency (EMA) for rheumatologic indications and those for which the biooriginator no longer is protected by patent, have been marketed. CTP-13, otherwise known as Remsima/Inflectra, was the first biosimilar approved by the EMA in September 2013. In January 2016, the EMA approved the first Etanercept biosimilar, SB4, otherwise known as Benepali. A further infliximab biosimilar, SB2/Flixabi, was approved in May 2016. In March 2017, the EMA approved the first Adalimumab biosimilar, SB5, otherwise known as Amgevita/Solymbic. The approval dates just mentioned represent the date of issue of a marketing authorisation valid throughout the European Union (EU). Currently, there are 700 biosimilar products in preclinical and clinical trials. Table 2 summarises the biosimilar studies to date (with relevance for the axSpA indication).

In 2015, the BSR published a position statement(39) on the use of biosimilars in practice. Notably, it was recommended that biosimilars should be prescribed by brand name rather than by non-proprietary name. This recommendation was in line with existing recommendations by the Medicines and Healthcare Products Regulatory Agency (MHRA) to avoid automatic or accidental substitution of a biosimilar product when the drug is issued by a pharmacist. The BSR have reiterated that clinical effectiveness and patient safety should be the overriding principles for prescribing any biologic agent and that prescribing should be on a case by case basis, based on clinical reasons and not solely as a measure to save money. 
Table 2. Biosimilar studies (with relevance for the axSpA indication) demonstrating safety and efficacy in rheumatic diseases

\begin{tabular}{|c|c|c|c|c|c|c|}
\hline Originator/Biosimilar & Study design & Indication(s) & $\begin{array}{l}\begin{array}{l}\text { No of } \\
\text { patients }\end{array} \\
\end{array}$ & $\begin{array}{l}\text { Type of } \\
\text { switch }\end{array}$ & $\begin{array}{l}\text { Follow-up post } \\
\text { switch }\end{array}$ & Reference(study name) \\
\hline Infliximab/CT-P13 & DB RCT multi-centre & $\begin{array}{l}\text { Crohn's, UC, SpA, RA, } \\
\text { PsA, Psoriasis }\end{array}$ & 408 & $\begin{array}{l}\text { One way } \\
\text { bo } \rightarrow \text { bs }\end{array}$ & 52 weeks & $\begin{array}{l}\text { Jorgensen et al, } 2017 \text { (NOR- } \\
\text { SWITCH)(40) }\end{array}$ \\
\hline Infliximab/CT-P13 & $\begin{array}{l}\text { OL extension of DB } \\
\text { RCT }\end{array}$ & RA & 302 & $\begin{array}{l}\text { One way } \\
\text { bo } \rightarrow \text { bs }\end{array}$ & 48 weeks & $\begin{array}{l}\text { Yoo D.H et al, } 2016 \\
\text { (PLANETRA)(41) }\end{array}$ \\
\hline Infliximab/CT-P13 & $\begin{array}{l}\text { OL extension of DB } \\
\text { RCT }\end{array}$ & AS & 174 & $\begin{array}{l}\text { One way } \\
\text { bo } \rightarrow \text { bs }\end{array}$ & 48 weeks & $\begin{array}{l}\text { Park W, et al } 2015 \\
\text { (PLANETAS)(42) }\end{array}$ \\
\hline Infliximab/CT-P13 & Observational registry & $\begin{array}{l}\text { RA, axial SpA, PsA, } \\
\text { other polyarthritis }\end{array}$ & 96 & $\begin{array}{l}\text { One way } \\
\text { bo } \rightarrow \text { bs }\end{array}$ & $2-4$ months & Glintborg B. et al, 2016 (43) \\
\hline Infliximab/CT-P13 & $\begin{array}{l}\text { Observational single } \\
\text { center study }\end{array}$ & $\begin{array}{l}\text { RA, SpA, PsA, JIA, } \\
\text { chronic reactive } \\
\text { arthritis }\end{array}$ & 39 & $\begin{array}{l}\text { One way } \\
\text { bo } \rightarrow \text { bs }\end{array}$ & variable & $\begin{array}{l}\text { Nikiphorou E et al, } 2015 \\
\text { (44) }\end{array}$ \\
\hline Infliximab/SB2 & DB RCT & RA & 396 & $\begin{array}{l}\text { One way } \\
\text { bo } \rightarrow \text { bs }\end{array}$ & 24 weeks & Smolen J. S. et al, 2016 (45) \\
\hline Infliximab/SB2 & DB RCT & RA & 584 & $\begin{array}{l}\text { No switch } \\
\text { Inflix v SB2 }\end{array}$ & 30 weeks & Choe et al, 2015(45) \\
\hline Infliximab/innovator biosimilar & $\begin{array}{l}\text { Observational } \\
\text { Multi-centre }\end{array}$ & $\begin{array}{l}\text { SpA/PsA } \\
\text { Undifferentiated SpA }\end{array}$ & 41 & $\begin{array}{l}\text { One way } \\
\text { bo } \rightarrow \text { bs }\end{array}$ & 6 months & Benucci et al, 2017(46) \\
\hline Etanercept/SB4 & $\begin{array}{l}\text { OL extension of DB } \\
\text { RCT }\end{array}$ & RA & 245 & $\begin{array}{l}\text { One way } \\
\text { bo } \rightarrow \text { bs }\end{array}$ & 48 weeks & Emery P et al, 2017 (47) \\
\hline Etanercept/SB4 & SB crossover & - & 138 & $\begin{array}{l}\text { One way } \\
\text { bo } \rightarrow \text { bs } \\
\text { bs } \rightarrow \text { bo }\end{array}$ & 20 days & Lee Y. et al, 2016 (48) \\
\hline Etanercept/GP2015 & Two way crossover & - & 54 & $\begin{array}{l}\text { One way } \\
\text { bo } \rightarrow \text { bs } \\
\text { bs } \rightarrow \text { bo }\end{array}$ & 28 days & Von Richter et al, 2017 (49) \\
\hline Etanercept/ABP 501 & DB RCT & RA & 494 & $\begin{array}{l}\text { One way } \\
\text { bo } \rightarrow \text { bs }\end{array}$ & 24 weeks & Cohen et al, 2017(50) \\
\hline Adalimumab/SB5 & DB RCT & RA & 508 & $\begin{array}{l}\text { One way } \\
\text { bo } \rightarrow \text { bs }\end{array}$ & 28 weeks & $\begin{array}{l}\text { WeinblattM. et al EULAR } \\
2016 \text { abstract FRI0161(51) }\end{array}$ \\
\hline
\end{tabular}

\section{Predictors of response to biologic therapy}

The biologics registries have shown that factors associated with clinical response include raised inflammatory markers, higher ASDAS score, lower BASFI, and younger age at baseline (52-54). According to the Swedish register, male gender and presence of peripheral arthritis were also baseline predictors of continuation of anti-TNF therapy (55). Similar findings have also been reported in a large cohort of AS patients treated with Adalimumab. In this study HLA-B27 positivity and anti-TNF naivety were associated with better response to Adalimumab (BASDAI50, ASAS40) (56). Shorter disease duration (57) and active inflammatory lesions on MRI have also been shown to predict response to TNF therapy (58). The use of corticosteroids has been associated with a poor response to Infliximab in a small retrospective study of 70 patients with AS treated with Infliximab over a five-year period. In this study $71.4 \%$ patients responded within the first 6 months of treatment (59).

Pederson et al (60) investigated the demographic, smoking status, presence of HLA B27, NSAID use and baseline CRP in 480 patients with AS commenced on anti-TNF therapy. They also assessed MRI at baseline, 3-6 months and annually. They found that the strongest predictor of treatment survival was normalised CRP or low disease activity within the first year of anti-TNF therapy. Sustained remission was more likely in patients achieving normal CRP with definite SIJ erosion and absence of ankylosis. Current smoking was a negative factor associated with achieving sustained remission. Ciurea et al(61) assessed response rates to anti-TNF in nr-axSpA versus AS in a SWISS cohort of 152 women and 267 men who fulfilled ASAS axSpA classification criteria. Interestingly, they found that a significantly lower number of women with nr-axSpA achieved an ASAS40 response with anti-TNF compared with those 
with AS. Responses were comparable in men with nr-axSpA and AS. More work is needed in this area to inform the optimisation of anti-TNF therapy in axSpA.

\section{Switching biologics}

Primary failure describes no response or inadequate efficacy in patients within 3-6 months of treatment with a biologic (62). A prospective multicentre longitudinal observational study using the Norwegian register, NOR-DMARD, assessed 514 patients with AS treated with anti-TNF (including Infliximab, Etanercept, and Adalimumab) of whom 77 switched to a second anti-TNF agent. The reason for switching was adverse events in 44 patients $(57.1 \%)$ and insufficient response in 30 (38.9\%) of the 77 switchers. The insufficient response group had been treated with the first TNF blocker for a median of 294 days, and the adverse event group has been treated with the first anti-TNF agent for a median of 171 days. For the first anti-TNF, the 2-year drug survival rate was $65 \%$, and for the second anti-TNF it was $60 \%$. The 3month BASDAI 50 and ASAS 40 responses were achieved by $49 \%$ and $38 \%$ of the non-switchers, by $25 \%$ and $30 \%$ of switchers after the first TNF blocker, and by $28 \%$ and $31 \%$ after the second TNF agent. This study shows that switching to a second anti-TNF can be an effective approach in AS, with around one-third of patients showing a good clinical response and more than half of patients continuing the treatment for more than 2 years $(63)$.

Of the 1436 AS patients from the Danish biologics register (DANBIO), 30\% of patients switched to a second biologic and $10 \%$ switched to a third biologic. Switchers were more frequently women, had shorter disease duration, and higher BASDAI/BASFI and visual analogue scale (VAS) scores when they commenced their first anti-TNF agent. After 2 years of treatment, the response rates and drug survival were lower among switchers; however, $52 \%$ of them achieved response compared to $63 \%$ of nonswitchers, therefore switching to another anti-TNF agent should be considered irrespective of the reason for discontinuation of the initial TNF blocker (64).

Of the 229 AS patients treated with biologics from the Finnish biologics register (ROB-FIN), 13 patients (7\%) discontinued the first biologic due to lack of efficacy and 21 patients discontinued for unspecified reasons; 14 of these patients switched from Infliximab to Etanercept or Adalimumab. Adverse events occurred in $11 \%$ of the patients receiving their first biologic drug ( 25 of 229 patients). In this study, the dose of Infliximab was increased in more than a quarter of the patients in an attempt to improve response. There was also an extensive use of concomitant DMARDs such as Methotrexate and Sulfasalazine with biologic therapy, due to peripheral arthritis. The combination of DMARDs and Infliximab led to a rapid pain relief and improvement of patient's and physician's global assessments within six weeks, which was sustained at two years. A subgroup of AS patients with axial involvement only $(n=46)$, had an ASAS20 response in $79 \%$. The authors concluded that switching may be possible; however, the group of switchers in this study was small ( $13 \%$ of patients, $n=27)(65)$.

A retrospective analysis of 108 patients with severe AS on anti-TNF therapy showed that $15 \%$ were switched to a second anti-TNF agent, and two patients were switched to a third anti-TNF agent. Inefficacy was the most common reason for switching (67\%), followed by adverse events (28\%). At 69 months, $86 \%$ of patients who switched to a second anti-TNF drug were continuing treatment. Switching due to adverse events led to better response than switching due to inefficacy. Sustained benefit in AS patients treated with a second anti-TNF is similar to the efficacy seen following the initial anti-TNF therapy (66) (67)

In a 54-week, open-label, prospective study of patients with AS treated with Infliximab who failed to achieve or maintain an ASAS20 clinical response or had adverse events, were switched to Etanercept. At week 54, ASAS20, ASAS50, and ASAS70 response rates were $74 \%, 61 \%$, and $39 \%$ respectively. These 
figures suggest that switching to etanercept may be a good therapeutic option for patients who do not respond to Infliximab (68).

Some patients have a good initial response to biologic therapy which subsequently diminishes with time. This has been coined secondary failure and is defined as a loss of efficacy of a biologic agent after more than 6 months (62).

A longitudinal observational prospective study (69) evaluated the clinical response after switching from one anti-TNF agent to another in patients with AS and PsA over a 5-year period. A clinical response was seen in $75 \%$ of the patients who changed from Infliximab to Etanercept, and $57.1 \%$ who switched from Etanercept to Adalimumab. Patients who switched because of adverse events and lack or loss of efficacy, showed a similar clinical response; $70 \%$ and $61.5 \%$ respectively. In this study, $81.3 \%$ of patients who had switched from Infliximab to Etanercept continued the treatment, compared to only $57.1 \%$ of patients who had changed from Etanercept to Adalimumab maintained the treatment. Two of the three patients who stopped Adalimumab because of inadequate response had already failed the other two anti-TNF agents. This observation suggests that the failure of two TNF inhibitors predicts ineffectiveness to the third, which has been seen in previous data on RA patients. Patients with SpA with inadequate response or adverse events to one anti-TNF agent may be successfully treated with another, regardless of the reason for switching

Switching to a second anti-TNF agent was necessary in $24 \%$ of the AS patients, and $11 \%$ of AS received a third anti-TNF in an observational study (62). In this study, secondary failure was the main reason for switching to a second anti-TNF agent, followed by side effects and lack of efficacy, whereas the reasons for switching to a third anti-TNF were lack of efficacy, followed by side effects. As with the previous findings, patients with AS with loss of efficacy to the first anti-TNF who were switched to a second antiTNF had an adequate response, suggesting that switching anti-TNF for secondary failure may be beneficial in this group of patients

In a cross-sectional study of $467 \mathrm{SpA}$ patients drug survival and the reasons for switching anti-TNF therapy was studied (70). Of the 467 patients who started anti-TNF therapy, 28\% switched to a second and $8 \%$ switched to a third drug. The mean drug survival did not differ among the courses of anti-TNF. In this study, the main reasons for switching were lack or loss of efficacy and adverse events in $40 \%$ and $30 \%$ of switchers respectively. Switchers were more frequently women and had higher disease activity parameters (BASDAI, ESR, and patient's visual analogue scale (VAS) for pain and for global state) at the time of the study than non-switchers

In a retrospective study of 113 patients with AS treated with anti-TNF including Adalimumab, Etanercept, Infliximab, long term response to biological therapy in AS in a real life clinical setting was investigated (71). This study looked at quantifying non-response and response to switching therapies. At week $12,88 \%$ of the patients responded to their first anti-TNF. Primary non-response was seen in 13 patients (infliximab $n=10$, etanercept $n=3$ ), 7 of whom were switched to a second anti-TNF, with 6 showing a good clinic response, all to etanercept. A further 8 patients who initially responded to the initial biologic were also switched and the reasons were secondary failure to Infliximab $(n=2)$, side effects $(n=2)$ or patient choice $(n=4)$. The primary and secondary non-response rates were less than $15 \%$. Disease duration, HLA-B27 status or biologic drug used, did not show any differences in the response rates. The majority of non-responders had a good response when switched to another anti-TNF, supporting switching in this group of patients.

\section{Radiographic progression}


Despite its clear clinical efficacy, there is controversy regarding biologic therapy and disease modification in axSpA. Studies have shown clear inhibition of radiographic progression in patients with rheumatoid arthritis and psoriatic arthritis. However, these findings have not been replicated in studies of axSpA.

Radiographic progression in AS develops slowly and may be detectable only after a minimum of two years. Ethically, it is difficult to justify a placebo arm of two years when the clinical benefits of the treatment are well known and occur shortly after it is commenced. Thus, studies assessing radiographic progression in axSpA have either used observational data or compared the open-label extension phase of RCT of TNF inhibitors with historical cohorts not treated with TNF inhibitors. These historical cohorts include the Outcome in Ankylosing Spondylitis International Study (OASIS), the German Spondyloarthritis Inception Cohort (GESPIC) and the Herne Cohort (HC).

Baraliakos et al (72) analysed radiographs of patients from a multi-centre, double-blind, placebo controlled trial in Germany which assessed the safety and efficacy of Infliximab over two years(73). They compared radiographic images to the German AS Cohort (GESPIC) cohort who were treated conventionally; 82 patients were included in the study; 41 patients were randomly picked from the continuous treatment arm of the RCT and 41 patients were randomly selected from the GESPIC cohort. The mean modified Stoke Ankylosing Spondylitis Spine Score (mSASSS) change in the Infliximab group was less than in conventionally treated patients but not significant so $(p=0.085)$. Van der Heijde et al looked at radiographs at baseline and at week 96 from patients in the ASSERT trial and compared this to radiographs from patients from the OASIS cohort who were anti-TNF naive (74). In this study Infliximab treated patients did not show a statistically significant difference in inhibition of structural damage progression at year 2, as assessed using the mSASSS scoring system, when compared with radiographic data from the historical control OASIS cohort.

Van der Heijde assessed a total of 257 patients treated with Etanercept and compared radiographs with 175 unselected patients from the OASIS study. No significant difference was found in the mean change (SD) in mSASSS from baseline among patients who received Etanercept 0.91 (2.45) versus those from the OASIS group 0.95 (3.18) (75). The same group looked at radiographs from patients in the ATLAS study combined with a Canadian AS study $(n=307)$. Radiographic progression from baseline to 2 years in the spine of these patients was compared to anti-TNF naive patients from the OASIS cohort $(\mathrm{n}=169)$. Again, mSASSS results were not significantly different between the Adalimumab cohort and the OASIS cohort after 2 years.

Baraliakos et al (76) assessed the rate of new bone formation after 8 years of Infliximab treatment in patients with AS. They compared the radiographic progression of 22 patients from the multi-centre DIKAS study (77). In DIKAS, all patients were treated with $5 \mathrm{mg} / \mathrm{kg}$ Infliximab continuously every 6 weeks. They compared radiographic changes to those in the Herne Cohort. The selection of patients was made according to their availability of conventional radiographs of the cervical and lumbar spine at baseline and whether they continued anti-TNF for 8 years. Patients on Infliximab $(n=22)$ and the Herne Cohort $(n=34)$ did not differ in the baseline mSASSS status. Both showed significant radiographic progression after 8 years with a mean (SD) mSASSS of 20.2 (21.4) in DIKAS and 25.9 (17.8) in Herne Cohort. The mean mSASSS difference was similar in both groups between baseline and four years but radiographic progression between years 4 and 8 differed significantly between both treatment groups $(\mathrm{p}=0.01)$. The mean number of syndesmophytes, although similar at baseline differed significantly at 8 years $(\mathrm{p}=0.007)$. Adjustment for age, symptoms duration, HLA B27, BASDAI and Bath AS function index (BASFI) at baseline had no influence. This finding implies that delays in radiographic progression may occur but after a protracted period of time.

Haroon et al (78) designed a prospective study looking at all patients who satisfied the modified New York criteria for AS. The study found that those who received TNF inhibitors had a 50\% reduction in 
odds progression to those who had not been on anti-TNF (OR: 0.52; CI 0.30-0.88 p =0.02). The total duration of treatment was inversely associated with progression compared to those who has not been on TNF inhibitors (OR: 0.52; CI 0.30-0.88; $\mathrm{p}=0.02$ ). Patients who were on biologics for more than $50 \%$ of their disease duration had lower odds of progression (OR 0.2 95\% CI: 0.04-0.92; $p=0.04$ ) compared to patients who were not. Patients who were not on anti-TNF for the greater part of their disease duration, had higher rates of mSASSS progression. In the patients who were on TNF-inhibitors, the rate of mSASSS progression increased with an increasing delay in starting treatment. This was the first study to show an association between the use of TNF inhibitors and progression of damage in AS. Haroon et al suggested that both the timing and duration of therapy could be important in rate of radiographic change. However, this study also raises methodological concerns, as it used a controversial definition of radiographic progression, the analyses did not take into account treatment changes and clinical changes between the 2 radiographic assessments and did not entirely account for time-varying variables in the statistical models (79).

A more recent observational cohort study by Maas et al looked at 176 AS patients receiving long-term TNF inhibitors and showed a reduction in spinal radiographic progression after more than 4 years of follow-up (80). These results may refer to a delayed effect of TNF inhibitors on radiographic progression. This finding supports the purported 'TNF brake hypothesis': That already-triggered repair processes can first lead to continuation of bone formation but long-term inhibition of inflammation by TNF inhibitors may result in a reduction of new bone formation overtime.

Finally, an even more recent study by Molnar et al (81), using 432 patients with AS in the Swiss Clinical Quality Management cohort with up to 10 years of follow-up and radiographic assessments every 2 years, demonstrated an association between TNF inhibitors 'use and reduced risk of spinal structural damage, both in terms of mSASSS and new syndesmophyte formation. This effect was mediated by a decrease in disease activity (reduction in ASDAS/CRP).

In the RAPID-axSpA Certolizumab trial, after 4 years, $80.6 \%$ of patients with AS did not progress $(<2$ mSASSS points change from baseline) and the mean change was 0.98 . The limited progression over 4 years observed in this study in patients with AS is consistent with MEASURE 1 Secukinumab trial, in which $79 \%$ of patients with AS treated with secukinumab did not progress (same definition: $<2$ mSASSS points change from baseline) over 4 years. However, none of these studies had a control group and therefore these findings cannot be used in isolation to confirm an effect of any of the drugs on structural damage (82)(83)

\section{Biologic therapies on the horizon}

The TOPAS trial gave promise to the inhibition of IL23 and IL12 with Ustekinumab in the treatment of ax-SpA. This was a 28-week, prospective, open-label study in patients with AS and prompted 3 subsequent phase 3 placebo controlled trials (NCT02437162, NCT02438787 and NCT02407223) assessing the safety and efficacy of Ustekinumanb in patients with both nr-axSpA and AS. However, this trial has been withdrawn as it has failed to meet any of its primary or secondary outcomes. A number of other biologics acting on the IL-17 and IL-23 axis are currently in clinical trials (Table 3).

Biologic drugs targeting other pathways, such as IL-1 and IL-6 blockers, B-cell depletion strategies and inhibition of T-cell costimulation, have been tested in uncontrolled or controlled trials in established AS. Trials on Anakinra (84)'(85), Abatacept(86), Rituximab (87)'(88) and Tocilizumab (89) have shown no consistent efficacy.

Whilst Apremilast and Tofacitinib are not biologic therapies, they have shown some positive results in the treatment of axSpA. Apremilast is an oral phosphodiesterase 4 inhibitor that modulates inflammatory 
cytokines. It was evaluated in a double-blind, placebo-controlled, phase II study over 12 weeks in 38 patients with symptomatic AS with active disease on MRI. This small pilot study did not meet its primary end point; however Apremilast was associated with improvement in various clinical assessments including BASDAI, BASFI, and BASMI compared to placebo (90). A subsequent phase III multicentre, randomised trial assessing the efficacy and safety of Apremilast in active AS has been completed (NCT01583374). The results of which have not yet been published but preliminary online reports suggest a failure of Apremilast to meet the primary end point (ASAS 20 at week 16) (source: NCT01583374 study results, accessed 1 October 2017).

Tofacitinib is an oral Janus-kinase (JAK) inhibitor, which has proven to be effective in RA(91) and potentially might be also effective in axSpA. A phase II study of Tofacitinib in active AS has shown greater clinical efficacy compared with placebo in ASAS20 and other secondary endpoints in patients with active AS(92). Despite these positive results, the company that owns Tofacitinib has decided to discontinue their programme in axSpA. Another JAK inhibitor, Filgotinib, is currently being investigated for its safety and efficacy in AS (NCT03117270).

Table 3. Novel biologics and Janus-kinase (JAK) inhibitors in clinical trials in axSpA

\begin{tabular}{|c|c|c|c|c|}
\hline Drug & Mechanism of action & Study Design & Patients & Trial number \\
\hline Ustekinumab & $\begin{array}{l}\text { monoclonal antibody - blocks IL } 23 \text { and } \\
\text { IL12 by binding to the common p } 40 \\
\text { subunit }\end{array}$ & Phase 3 multi-center, DB RCT & axSp & $\begin{array}{l}\text { NCT02437162 } \\
\text { NCT02438787 NCT02407223 }\end{array}$ \\
\hline Ixekizumab & $\begin{array}{l}\text { humanized monoclonal antibody } \\
\text { against IL 17A }\end{array}$ & Phase 3 multi-center, DB RCT & axSpA & $\begin{array}{l}\text { NCT02696785 } \\
\text { NCT02696798 } \\
\text { NCT02757352 } \\
\text { NCT03129100 }\end{array}$ \\
\hline Bimekizumab & $\begin{array}{l}\text { monoclonal antibody inhibits IL-17A } \\
\text { and IL-17F }\end{array}$ & Phase 2B multi center DB RCT & AS & $\begin{array}{l}\text { NCT02963506 } \\
\text { NCT03215277 }\end{array}$ \\
\hline Brodalumab & $\begin{array}{l}\text { monoclonal antibody binds to the IL- } 17 \\
\text { receptor }\end{array}$ & Phase 3 multi-center, DB RCT & axSpA & NCT02985983 \\
\hline Risankizumab & $\begin{array}{l}\text { humanized monoclonal antiboc } \\
\text { against IL-23A }\end{array}$ & Phase 2, DB RCT & AS & NCT02047110 \\
\hline BCD085 & $\begin{array}{l}\text { humanised monoclonal antibody which } \\
\text { targets IL-17 }\end{array}$ & $\begin{array}{l}\text { International multi-center DB } \\
\text { RCT }\end{array}$ & AS & NCT02763111 \\
\hline Filgotinib & selective JAK1 inhibitor & Phase 2, DB RCT & AS & NCT03117270 \\
\hline
\end{tabular}




\section{Expert opinion}

We have witnessed a great improvement in the treatment of axSpA in the last few years. The future remains exciting for patients with axSpA and for clinicians treating these patients. For the first time in many years a new therapeutic approach has been approved (Secukinumab) and others show promise in axSpA, including small targeted molecules, such as JAK inhibitors. Despite the attention paid to biologic treatments, it is important to emphasise that NSAIDs continue to be the first-line treatment for patients with axSpA and that non-pharmacological treatment modalities are important in the management of these patients (exercise, physical therapy, smoking cessation).

Biosimilars are here to stay and may increase access to effective but expensive biologic therapies, with a desired positive impact on drug expenditures. This is a highly regulated area and current evidence has reduced the initial uncertainty about their use. Switching from bio-originator to biosimilar and extrapolation from one rheumatological indication to other diseases is now widely accepted given the significant amount of evidence that has accumulated about the safety and efficacy of biosimilars. However, switching should be based on a shared decision-making process between patients and rheumatologists, and should take healthcare systems' contextual factor into account. Some concern remains about multiple switching between biosimilars and their bio-originators or other biosimilars. Importantly, harmonised methods are being suggested and established to obtain reliable pharmacovigilance data, including traceability about both biosimilars and bio-originators (93).

Trying to establish which patients benefit the most from each drug is a challenge for the future. There are very few head to head studies comparing the efficacy of biologics in patients with axSpA. Giardina et al investigated Etanercept versus Infliximab in the treatement of AS and found a significantly more rapid clinical improvement in the infliximab treated group (94). However, this is the only head to head study and further studies need to be carried out to test this finding. Selection of biologics may be dependent on patients' preferences/lifestyle and clinical characteristics should be considered, namely the presence of certain extra-articular features. Monoclonal antibodies (Adalimumab, Infliximab and Certolizumab; no data on Golimumab) have been shown to be efficacious in preventing the recurrence of uveitis and in the treatment of inflammatory bowel disease (IBD), whereas Etanercept has shown contradictory results for uveitis, less efficacy in psoriasis and is not efficacious in IBD (95)'(96)'(97)'(98)'(73)'(99)'(100)'(101)' On the other hand, Etanercept seems to have a lower tuberculosis risk compared to monoclonal antibody TNF-blockers(102). Data suggest that Secukinumab should be avoided in patients with active IBD, as Secukinumab in comparison to placebo was not efficacious in Crohn's disease and resulted in more adverse events (103). It remains to be conclusively shown if any of these drugs will be able to stop or delay radiographic progression.

\section{Highlights Box: Biologics in axial spondyloarthritis}

Biologics in axial spondyloarthritis:

1. Significant advances have been made in the treatment of axSpA.

2. Despite the efficacy of biologics, NSAIDs continue to be the first-line treatment for patients with axSpA, and non-pharmacological treatment modalities continue to be important in the management of these patients.

3. For the first time in many years a new therapeutic approach has been approved (targeting IL-17) and others show promise in axSpA.

4. The introduction of biosimilars has greatly reduced the cost associated with biologic treatment.

5. Trying to establish which patients benefit the most from each drug is a challenge for the future. 


\section{FUNDING}

PM Machado was supported by the National Institute for Health Research University College London Hospitals Biomedical Research Centre for this paper.

\section{DECLARATION OF INTEREST}

PM Machado has consultancy/speaker fees from AbbVie, Centocor, Janssen, MSD, Novartis, Pfizer and UCB Pharma. The authors have no other relevant affiliations or financial involvement with any organization or entity with a financial interest in or financial conflict with the subject matter or materials discussed in the manuscript apart from those disclosed. One peer reviewer has been a speaker or consultant for all companies that currently market a biological treatment in the field (all fees are collected by the reviewer's university's tech transfer department and are not a direct part of the reviewer's income). Peer reviewers on this manuscript have no other relevant financial or other relationships to disclose

\section{REFERENCES}

Papers of special note have been highlighted as:

$*$ of interest

** of considerable interest

1. Dougados M, Baeten D. Spondyloarthritis. Lancet (London, England) [Internet]. 2011 Jun 18 [cited 2017 May 3];377(9783):2127-37. Available from: http://linkinghub.elsevier.com/retrieve/pii/S0140673611600718

2. Stolwijk C, van Onna M, Boonen A, van Tubergen A. Global Prevalence of Spondyloarthritis: A Systematic Review and Meta-Regression Analysis. Arthritis Care Res (Hoboken) [Internet]. 2016 Sep [cited 2017 May 3];68(9):1320-31. Available from: http://doi.wiley.com/10.1002/acr.22831

3. Rudwaleit M, van der Heijde D, Landewe R, Listing J, Akkoc N, Brandt J, et al. The development of Assessment of SpondyloArthritis international Society classification criteria for axial spondyloarthritis (part II): validation and final selection. Ann Rheum Dis [Internet]. 2009 Jun 1 [cited 2017 May 3];68(6):777-83. Available from: http://ard.bmj.com/cgi/doi/10.1136/ard.2009.108233

4. **Rudwaleit $\mathrm{M}$, van der Heijde $\mathrm{D}$, Landewé $\mathrm{R}$, Akkoc N, Brandt J, Chou CT, et al. The Assessment of SpondyloArthritis International Society classification criteria for peripheral spondyloarthritis and for spondyloarthritis in general. Ann Rheum Dis [Internet]. 2011 Jan [cited 2017 May 3];70(1):25-31. Available from: http://www.ncbi.nlm.nih.gov/pubmed/21109520

** Seminal paper on the ASAS classification criteria of axSpA

5. Benhamou M, Gossec L, Dougados M. Clinical relevance of C-reactive protein in ankylosing spondylitis and evaluation of the NSAIDs/coxibs' treatment effect on C-reactive protein. Rheumatology (Oxford) [Internet]. 2010 Mar 1 [cited 2017 May 3];49(3):536-41. Available from: https://academic.oup.com/rheumatology/article-lookup/doi/10.1093/rheumatology/kep393

6. Wanders A, Heijde D van der, Landewé R, Béhier J-M, Calin A, Olivieri I, et al. Nonsteroidal antiinflammatory drugs reduce radiographic progression in patients with ankylosing spondylitis: A randomized clinical trial. Arthritis Rheum [Internet]. 2005 Jun [cited 2017 May 3];52(6):1756-65. Available from: http://www.ncbi.nlm.nih.gov/pubmed/15934081

7. *Sieper J, Listing J, Poddubnyy D, Song I-H, Hermann K-G, Callhoff J, et al. Effect of continuous versus on-demand treatment of ankylosing spondylitis with diclofenac over 2 years on radiographic progression of the spine: results from a randomised multicentre trial (ENRADAS). Ann Rheum Dis [Internet]. 2016 Aug [cited 2017 May 3];75(8):1438-43. Available from: http://ard.bmj.com/lookup/doi/10.1136/annrheumdis-2015-207897

*An excellent paper demonstrating that continuous NSAID use does not delay reduce radiographic progression in axSpA

8. Kroon F, Landewe R, Dougados M, van der Heijde D. Continuous NSAID use reverts the effects 
of inflammation on radiographic progression in patients with ankylosing spondylitis. Vol. 71, Annals of the Rheumatic Diseases. 2012. p. 1623-9.

9. Poddubnyy D, Rudwaleit M, Haibel H, Listing J, Märker-Hermann E, Zeidler H, et al. Effect of non-steroidal anti-inflammatory drugs on radiographic spinal progression in patients with axial spondyloarthritis: results from the German Spondyloarthritis Inception Cohort. Ann Rheum Dis [Internet]. 2012 Oct [cited 2017 May 3];71(10):1616-22. Available from: http://ard.bmj.com/lookup/doi/10.1136/annrheumdis-2011-201252

10. **Sepriano A, Regel A, van der Heijde D, Braun J, Baraliakos X, Landewé R, et al. Efficacy and safety of biological and targeted-synthetic DMARDs: a systematic literature review informing the 2016 update of the ASAS/EULAR recommendations for the management of axial spondyloarthritis. RMD Open [Internet]. 2017 Jan 27 [cited 2018 Feb 22];3(1):e000396. Available from: http://www.ncbi.nlm.nih.gov/pubmed/28176964

$* *$ This is an excellent review of the efficacy and safety of biologics in axSpA

11. **van der Heijde D, Ramiro S, Landewé R, Baraliakos X, Van den Bosch F, Sepriano A, et al. 2016 update of the ASAS-EULAR management recommendations for axial spondyloarthritis. Ann Rheum Dis [Internet]. 2017 Jun [cited 2017 Sep 18];76(6):978-91. Available from: http://www.ncbi.nlm.nih.gov/pubmed/28087505

** European recommendations for the management of axSpA

12. **Ward MM, Deodhar A, Akl EA, Lui A, Ermann J, Gensler LS, et al. American College of Rheumatology/Spondylitis Association of America/Spondyloarthritis Research and Treatment Network 2015 Recommendations for the Treatment of Ankylosing Spondylitis and Nonradiographic Axial Spondyloarthritis. Arthritis Rheumatol. 2016;68(2):282-98.

** American recommendations for the management of axSpA

13. Hamilton L, Barkham N, Bhalla A, Brittain R, Cook D, Jones G, et al. BSR and BHPR guideline for the treatment of axial spondyloarthritis (including ankylosing spondylitis) with biologics. Rheumatology [Internet]. 2017 Feb 1 [cited 2018 Feb 8];56(2):313-6. Available from: https://academic.oup.com/rheumatology/article-lookup/doi/10.1093/rheumatology/kew223

14. TNF-alpha inhibitors for ankylosing spondylitis and non-radiographic axial spondyloarthritis | Guidance and guidelines I NICE. [cited 2018 Feb 8]; Available from: https://www.nice.org.uk/guidance/ta383/chapter/1-recommendations

15. van der Heijde D, Kivitz A, Schiff MH, Sieper J, Dijkmans BAC, Braun J, et al. Efficacy and safety of adalimumab in patients with ankylosing spondylitis: Results of a multicenter, randomized, double-blind, placebo-controlled trial. Arthritis Rheum [Internet]. 2006 Jul [cited 2017 May 3];54(7):2136-46. Available from: http://www.ncbi.nlm.nih.gov/pubmed/16802350

16. Sieper J, van der Heijde D, Dougados M, Mease PJ, Maksymowych WP, Brown MA, et al. Efficacy and safety of adalimumab in patients with non-radiographic axial spondyloarthritis: results of a randomised placebo-controlled trial (ABILITY-1). Ann Rheum Dis [Internet]. 2013 Jun [cited 2017 May 3];72(6):815-22. Available from: http://ard.bmj.com/lookup/doi/10.1136/annrheumdis-2012-201766

17. Sieper J, van der Heijde D, Dougados M, Brown LS, Lavie F, Pangan AL. Early response to adalimumab predicts long-term remission through 5 years of treatment in patients with ankylosing spondylitis. Ann Rheum Dis [Internet]. 2012 May [cited 2017 May 3];71(5):700-6. Available from: http://ard.bmj.com/lookup/doi/10.1136/annrheumdis-2011-200358

18. Landewé R, Braun J, Deodhar A, Dougados M, Maksymowych WP, Mease PJ, et al. Efficacy of certolizumab pegol on signs and symptoms of axial spondyloarthritis including ankylosing spondylitis: 24-week results of a double-blind randomised placebo-controlled Phase 3 study. Ann Rheum Dis [Internet]. 2014 Jan [cited 2017 May 3];73(1):39-47. Available from: http://ard.bmj.com/lookup/doi/10.1136/annrheumdis-2013-204231

19. van der Heijde D, Dougados M, Landewé R, Sieper J, Maksymowych WP, Rudwaleit M, et al. Sustained efficacy, safety and patient-reported outcomes of certolizumab pegol in axial spondyloarthritis: 4-year outcomes from RAPID-axSpA. Rheumatology [Internet]. 2017 May 12 
[cited 2017 Oct 2];56(9):1498-509. Available from:

https://academic.oup.com/rheumatology/article-lookup/doi/10.1093/rheumatology/kex174

20. Braun J, Baraliakos X, Hermann K-G, Landewé R, Machado PM, Maksymowych WP, et al. Effect of certolizumab pegol over 96 weeks of treatment on inflammation of the spine and sacroiliac joints, as measured by MRI, and the association between clinical and MRI outcomes in patients with axial spondyloarthritis. RMD Open [Internet]. 2017 Apr 24 [cited 2017 Oct 2];3(1):e000430. Available from: http://www.ncbi.nlm.nih.gov/pubmed/28848654

21. Davis JC, van der Heijde DM, Braun J, Dougados M, Cush J, Clegg D, et al. Sustained durability and tolerability of etanercept in ankylosing spondylitis for 96 weeks. Ann Rheum Dis [Internet]. 2005;64(11):1557-62. Available from: http://www.ncbi.nlm.nih.gov/pubmed/15843448\%5Cnhttp://www.pubmedcentral.nih.gov/articlere nder.fcgi?artid=PMC1755272

22. Song I-H, Hermann K, Haibel H, Althoff C, Listing J, Burmester G, et al. Effects of etanercept versus sulfasalazine in early axial spondyloarthritis on active inflammatory lesions as detected by whole-body MRI (ESTHER): a 48-week randomised controlled trial. Ann Rheum Dis [Internet]. 2011 Apr 1 [cited 2017 May 3];70(4):590-6. Available from: http://ard.bmj.com/cgi/doi/10.1136/ard.2010.139667

23. Baraliakos X, Haibel H, Fritz C, Listing J, Heldmann F, Braun J, et al. Long-term outcome of patients with active ankylosing spondylitis with etanercept-sustained efficacy and safety after seven years. Arthritis Res Ther [Internet]. 2013 [cited 2017 May 3];15(3):R67. Available from: $\mathrm{http} / /$ arthritis-research.biomedcentral.com/articles/10.1186/ar4244

24. Dougados M, van der Heijde D, Sieper J, Braun J, Maksymowych WP, Citera G, et al. Symptomatic efficacy of etanercept and its effects on objective signs of inflammation in early nonradiographic axial spondyloarthritis: a multicenter, randomized, double-blind, placebocontrolled trial. Arthritis Rheumatol (Hoboken, NJ) [Internet]. 2014 Aug [cited 2017 Sep 18];66(8):2091-102. Available from: http://www.ncbi.nlm.nih.gov/pubmed/24891317

25. van der Heijde D, Dijkmans B, Geusens P, Sieper J, DeWoody K, Williamson P, et al. Efficacy and safety of infliximab in patients with ankylosing spondylitis: results of a randomized, placebocontrolled trial (ASSERT). Arthritis Rheum [Internet]. 2005 Feb [cited 2017 May 3];52(2):58291. Available from: http://doi.wiley.com/10.1002/art.20852

26. Baraliakos X, Listing J, Fritz C, Haibel H, Alten R, Burmester G-R, et al. Persistent clinical efficacy and safety of infliximab in ankylosing spondylitis after 8 years--early clinical response predicts long-term outcome. Rheumatology (Oxford) [Internet]. 2011 Sep 1 [cited 2017 May 3];50(9):1690-9. Available from: https://academic.oup.com/rheumatology/articlelookup/doi/10.1093/rheumatology/ker194

27. Inman RD, Davis JC, Heijde D Van Der, Diekman L, Sieper J, Kim S Il, et al. Efficacy and safety of golimumab in patients with ankylosing spondylitis: Results of a randomized, double-blind, placebo-controlled, phase III trial. Arthritis Rheum [Internet]. 2008 Nov [cited 2017 May 3];58(11):3402-12. Available from: http://www.ncbi.nlm.nih.gov/pubmed/18975305

28. Sieper J, van der Heijde D, Dougados M, Maksymowych WP, Scott BB, Boice JA, et al. A randomized, double-blind, placebo-controlled, sixteen-week study of subcutaneous golimumab in patients with active nonradiographic axial spondyloarthritis. Arthritis Rheumatol (Hoboken, NJ). 2015;67(10):2702-12.

29. *Baeten D, Sieper J, Braun J, Baraliakos X, Dougados M, Emery P, et al. Secukinumab, an Interleukin-17A Inhibitor, in Ankylosing Spondylitis. $\mathrm{N}$ Engl $\mathrm{J}$ Med [Internet]. 2015;373(26):2534-48. Available from: http://www.nejm.org/doi/10.1056/NEJMoa1505066

* Excellent paper on the evidence for Secukinumab in axSpA

30. van der Heijde D, Kivitz A, Schiff MH, Sieper J, Dijkmans BAC, Braun J, et al. Efficacy and safety of adalimumab in patients with ankylosing spondylitis: results of a multicenter, randomized, double-blind, placebo-controlled trial. Arthritis Rheum [Internet]. 2006;54(7):2136-46. Available from: 
http://www.embase.com/search/results?subaction=viewrecord\&from=export\&id=L44051069\%5C nhttp://dx.doi.org/10.1002/art.21913\%5Cnhttp://elvis.ubvu.vu.nl:9003/vulink?sid=EMBASE\&issn $=00043591 \&$ id $=$ doi: $10.1002 /$ art $21913 \&$ atitle $=$ Efficacy + and + safety + of + adalimumab + in +

31. Davis JC, Van Der Heijde D, Braun J, Dougados M, Cush J, Clegg DO, et al. Recombinant Human Tumor Necrosis Factor Receptor (Etanercept) for Treating Ankylosing Spondylitis: A Randomized, Controlled Trial. Arthritis Rheum. 2003;48(11):3230-6.

32. Van Der Heijde D, Dijkmans B, Geusens P, Sieper J, DeWoody K, Williamson P, et al. Efficacy and safety of infliximab in patients with ankylosing spondylitis: Results of a randomized, placebocontrolled trial (ASSERT). Arthritis Rheum. 2005;52(2):582-91.

33. Kavanaugh A, Van Der Heijde D, McInnes IB, Mease P, Krueger GG, Gladman DD, et al. Golimumab in psoriatic arthritis: One-year clinical efficacy, radiographic, and safety results from a phase III, randomized, placebo-controlled trial. Arthritis Rheum. 2012;64(8):2504-17.

34. Dougados M, Braun J, Szanto S, Combe B, Elbaz M, Geher P, et al. Efficacy of etanercept on rheumatic signs and pulmonary function tests in advanced ankylosing spondylitis: Results of a randomised double-blind placebo-controlled study (SPINE). Ann Rheum Dis. 2011;70(5):799_ 804.

35. Dougados M, Van Der Heijde D, Sieper J, Braun J, Maksymowych WP, Citera G, et al. Symptomatic efficacy of etanercept and its effects on objective signs of inflammation in early nonradiographic axial spondyloarthritis: A multicenter, randomized, double-blind, placebocontrolled trial. Arthritis Rheumatol. 2014;66(8):2091-102.

36. Sieper J, van der Heijde D, Dougados M, Maksymowych WP, Boice JA, Bergman G, et al. THU0238 A Randomized, Double-Blind, Placebo-Controlled, 16-Week Study of Subcutaneous Golimumab in Patients with Active Nonradiographic Axial Spondyloarthritis. Ann Rheum Dis. 2015;74(Suppl 2):283.1-283.

37. - World Health Organization. Expert Committee on Biological Standardization. Geneva, 19 to 23 October 2009. Guidelines on evaluation of similar biotherapeutic products (SBPs). Available from: www.who.int/biologicals/areas/biological_therapeutics/BIOTHERAP.

38. Haustein R. Saving money in the European healthcare systems with biosimilars. Generics Biosimilars Initiat. 2012;1(3):120-6.

39. January 2017 Position statement: Biosimilar medicines. [cited 2018 Feb 8]; Available from: https://www.rheumatology.org.uk/Portals/0/Policy/Policy Statements/Biosimilars.pdf

40. Jørgensen KK, Olsen IC, Goll GL, Lorentzen M, Bolstad N, Haavardsholm EA, et al. Switching from originator infliximab to biosimilar CT-P13 compared with maintained treatment with originator infliximab (NOR-SWITCH): a 52-week, randomised, double-blind, non-inferiority trial. Lancet (London, England) [Internet]. 2017 [cited 2017 Sep 18];389(10086):2304-16. Available from: http://www.ncbi.nlm.nih.gov/pubmed/28502609

41. Yoo DH, Prodanovic N, Jaworski J, Miranda P, Ramiterre E, Lanzon A, et al. Efficacy and safety of CT-P13 (biosimilar infliximab) in patients with rheumatoid arthritis: comparison between switching from reference infliximab to CT-P13 and continuing CT-P13 in the PLANETRA extension study. Ann Rheum Dis [Internet]. 2016;13:annrheumdis-2015-208786. Available from: http://ard.bmj.com/lookup/doi/10.1136/annrheumdis-2015-208786

42. Park W, Yoo DH, Miranda P, Brzosko M, Wiland P, Gutierrez-Ureña S, et al. Efficacy and safety of switching from reference infliximab to CT-P13 compared with maintenance of CT-P13 in ankylosing spondylitis: 102-week data from the PLANETAS extension study. Ann Rheum Dis [Internet]. 2016;annrheumdis-2015-208783-. Available from: http://ard.bmj.com/content/early/2016/04/28/annrheumdis-2015-208783

43. Glintborg B, Kringelbach T, Høgdall E, Sørensen IJ, Jensen DV, Loft AG, et al. THU0123 NonMedical Switch from Originator To Biosimilar Infliximab among Patients with Inflammatory Rheumatic Disease - Impact on S-Infliximab and Antidrug-Antibodies. Results from The National Danish Rheumatologic Biobank and The Danbio Registry. Ann Rheum Dis [Internet]. 2016 Jun 1 [cited 2017 Sep 18];75(Suppl 2):224-224. Available from: 
http://ard.bmj.com/content/75/Suppl_2/224.2

44. Nikiphorou E, Kautiainen H, Hannonen P, Asikainen J, Kokko A, Rannio T, et al. Clinical effectiveness of CT-P13 (Infliximab biosimilar) used as a switch from Remicade (infliximab) in patients with established rheumatic disease. Report of clinical experience based on prospective observational data. Expert Opin Biol Ther [Internet]. 2015;15(12):1677-83. Available from: http://www.tandfonline.com.libgate.library.nuigalway.ie/doi/full/10.1517/14712598.2015.1103733 \#aHR0cDovL3d3dy50YW5kZm9ubGluZS5jb20ubGliZ2F0ZS5saWJyYXJ5Lm51aWdhbHdheS5 pZS9kb2kvcGRmLzEwLjE1MTcvMTQ3MTI1OTguMjAxNS4xMTAzNzMzQEBAMA=

45. Choe J-Y, Prodanovic N, Niebrzydowski J, Staykov I, Dokoupilova E, Baranauskaite A, et al. A randomised, double-blind, phase III study comparing SB2, an infliximab biosimilar, to the infliximab reference product Remicade in patients with moderate to severe rheumatoid arthritis despite methotrexate therapy. Ann Rheum Dis [Internet]. 2017 Jan 1 [cited 2017 Sep 18];76(1):58-64. Available from: http://www.ncbi.nlm.nih.gov/pubmed/26318384

46. Benucci M, Gobbi FL, Bandinelli F, Damiani A, Infantino M, Grossi V, et al. Safety, efficacy and immunogenicity of switching from innovator to biosimilar infliximab in patients with spondyloarthritis: a 6-month real-life observational study. Immunol Res [Internet]. [cited 2017 Sep 18];65(1):419-22. Available from: https://link.springer.com/article/10.1007/s12026-016-8843-5

47. Emery P, Vencovský J, Sylwestrzak A, Leszczyński P, Porawska W, Baranauskaite A, et al. A phase III randomised, double-blind, parallel-group study comparing SB4 with etanercept reference product in patients with active rheumatoid arthritis despite methotrexate therapy. Ann Rheum Dis [Internet]. 2017 Jan [cited 2017 Sep 18];76(1):51-7. Available from: http://www.ncbi.nlm.nih.gov/pubmed/26150601

48. Lee YJ, Shin D, Kim Y, Kang J, Gauliard A, Fuhr R. A randomized phase 1 pharmacokinetic study comparing SB4 and etanercept reference product (Enbrel $\left.{ }^{\circledR}\right)$ in healthy subjects. Br J Clin Pharmacol [Internet]. 2016 Jul [cited 2017 Sep 18];82(1):64-73. Available from: http://www.ncbi.nlm.nih.gov/pubmed/26972584

49. von Richter O, Skerjanec A, Afonso M, Sanguino Heinrich S, Poetzl J, Woehling H, et al. GP2015, a proposed etanercept biosimilar: Pharmacokinetic similarity to its reference product and comparison of its autoinjector device with prefilled syringes. Br J Clin Pharmacol [Internet]. 2017 Apr [cited 2017 Sep 18];83(4):732-41. Available from: http://www.ncbi.nlm.nih.gov/pubmed/27790726

50. Cohen S, Genovese MC, Choy E, Perez-Ruiz F, Matsumoto A, Pavelka K, et al. Efficacy and safety of the biosimilar ABP 501 compared with adalimumab in patients with moderate to severe rheumatoid arthritis: a randomised, double-blind, phase III equivalence study. Ann Rheum Dis [Internet]. 2017 Oct [cited 2017 Sep 18];76(10):1679-87. Available from: http://ard.bmj.com/lookup/doi/10.1136/annrheumdis-2016-210459

51. Weinblatt M, Baranauskaite A, Niebrzydowski J, Dokoupilova E, Zielinska A, Sitek-Ziolkowska K, et al. FRI0161 Sustained Efficacy and Comparable Safety and Immunogenicity after Transition To SB5 (An Adalimumab Biosimilar) vs Continuation of The Adalimumab Reference Product in Patients with Rheumatoid Arthritis: Result of Phase III Study. Ann Rheum Dis [Internet]. 2016

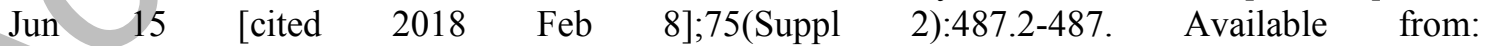
http://ard.bmj.com/lookup/doi/10.1136/annrheumdis-2016-eular.1762

52. Lord PAC, Farragher TM, Lunt M, Watson KD, Symmons DPM, Hyrich KL, et al. Predictors of response to anti-TNF therapy in ankylosing spondylitis: results from the British Society for Rheumatology Biologics Register. Rheumatology (Oxford) [Internet]. 2010 Mar 1 [cited 2017 May 3];49(3):563-70. Available from: https://academic.oup.com/rheumatology/articlelookup/doi/10.1093/rheumatology/kep422

53. Arends S, Brouwer E, van der Veer E, Groen H, Leijsma MK, Houtman PM, et al. Baseline predictors of response and discontinuation of tumor necrosis factor-alpha blocking therapy in ankylosing spondylitis: a prospective longitudinal observational cohort study. Arthritis Res Ther. 2011 Jun 20;13(3):R94. 
54. Glintborg B, Østergaard M, Krogh NS, Tarp U, Manilo N, Loft AGR, et al. Clinical response, drug survival and predictors thereof in 432 ankylosing spondylitis patients after switching tumour necrosis factor $\alpha$ inhibitor therapy: results from the Danish nationwide DANBIO registry. Ann Rheum Dis [Internet]. 2013 Jul [cited 2017 May 3];72(7):1149-55. Available from: http://ard.bmj.com/lookup/doi/10.1136/annrheumdis-2012-201933

55. Kristensen LE, Karlsson JA, Englund M, Petersson IF, Saxne T, Geborek P. Presence of peripheral arthritis and male sex predicting continuation of anti-tumor necrosis factor therapy in ankylosing spondylitis: An observational prospective cohort study from the South Swedish arthritis treatment group register. Arthritis Care \&amp; Res [Internet]. 2010 Oct 1 [cited 2017 Sep 18];62(10):1362-9. Available from: http://onlinelibrary.wiley.com/doi/10.1002/acr.20258/abstract

56. Rudwaleit M, Claudepierre P, Wordsworth P, Cortina EL, Sieper J, Kron M, et al. Effectiveness, safety, and predictors of good clinical response in 1250 patients treated with adalimumab for active ankylosing spondylitis. J Rheumatol. 2009;36(4):801-8.

57. Rudwaleit M, Listing J, Brandt J, Braun J, Sieper J. Prediction of a major clinical response (BASDAI 50) to tumour necrosis factor alpha blockers in ankylosing spondylitis. Ann Rheum Dis. 2004;63(Basdai 50):665-70.

58. Rudwaleit M, Schwarzlose S, Hilgert ES, Listing J, Braun J, Sieper J. MRI in predicting a major clinical response to anti-tumour necrosis factor treatment in ankylosing spondylitis. Ann Rheum Dis [Internet]. 2008;67(9):1276-81. Available from: http://www.ncbi.nlm.nih.gov/pubmed/18006539

59. Lorenzin M, Ortolan A, Frallonardo P, Oliviero F, Punzi L, Ramonda R. Predictors of response and drug survival in ankylosing spondylitis patients treated with infliximab. BMC Musculoskelet Disord [Internet]. 2015;16:1-8. Available from: http://www.pubmedcentral.nih.gov/articlerender.fcgi?artid=4513706\&tool=pmcentrez\&rendertype $=$ abstract

60. Pederson SJ et al. Presented at the 10th International Congress on Spondyloarthritides, 15-17 September 2016, Gent, Belgium (Poster P123).

61. In Contrast to Men, Women with Nonradiographic Axial Spondyloarthritis Have Lower Response Rates to TNF Inhibitors Than Women with Ankylosing Spondylitis - ACR Meeting Abstracts [Internet]. [cited 2017 Sep 18]. Available from: http://acrabstracts.org/abstract/in-contrast-to-menwomen-with-nonradiographic-axial-spondyloarthritis-have-lower-response-rates-to-tnf-inhibitorsthan-women-with-ankylosing-spondylitis/

62. Haberhauer G, Strehblow C, Fasching P. Observational study of switching anti-TNF agents in ankylosing spondylitis and psoriatic arthritis versus rheumatoid arthritis. Wiener Medizinische Wochenschrift. 2010;160(9-10):220-4.

63. Lie E, van der Heijde D, Uhlig T, Mikkelsen K, Rødevand E, Koldingsnes W, et al. Effectiveness of switching between TNF inhibitors in ankylosing spondylitis: data from the NOR-DMARD register. Ann Rheum Dis [Internet]. 2011;70(1):157-63. Available from: http://www.ncbi.nlm.nih.gov/pubmed/21062852

64. Glintborg B, Østergaard M, Krogh NS, Andersen MD, Tarp U, Loft AG, et al. Clinical response, drug survival, and predictors thereof among 548 patients with psoriatic arthritis who switched tumor necrosis factor?? inhibitor therapy: Results from the danish nationwide DANBIO registry. Arthritis Rheum. 2013;65(5):1213-23.

65. Konttinen L, Tuompo R, Uusitalo T, Luosujärvi R, Laiho K, Lähteenmäki J, et al. Anti-TNF therapy in the treatment of ankylosing spondylitis: The Finnish experience. Clin Rheumatol. 2007;26(10):1693-700.

66. Sammaritano LR. Therapy insight: guidelines for selection of contraception in women with rheumatic diseases. Nat Clin Pract Rheumatol [Internet]. 2007;3(5):273-81-6. Available from: http://www.ncbi.nlm.nih.gov/pubmed/17471246

67. Pradeep DJ, Keat AC, Gaffney K, Brooksby A, Leeder J, Harris C. Switching anti-TNF therapy in ankylosing spondylitis. Rheumatology [Internet]. 2008 Nov 1 [cited 2017 Sep 18];47(11):1726-7. 
Available from: https://academic.oup.com/rheumatology/article/47/11/1726/1789402/Switchinganti-TNF-therapy-in-ankylosing

68. Cantini F, Niccoli L, Benucci M, Chindamo D, Nannini C, Olivieri I, et al. Switching from infliximab to once-weekly administration of $50 \mathrm{mg}$ etanercept in resistant or intolerant patients with ankylosing spondylitis: Results of a fifty-four-week study. Arthritis Care \&amp; Res [Internet]. 2006 Oct 15 [cited 2017 Sep 18];55(5):812-6. Available from: http://onlinelibrary.wiley.com/doi/10.1002/art.22236/full

69. Conti F, Ceccarelli F, Marocchi E, Magrini L, Spinelli FR, Spadaro A, et al. Switching tumour necrosis factor alpha antagonists in patients with ankylosing spondylitis and psoriatic arthritis: an observational study over a 5-year period. Ann Rheum Dis [Internet]. 2007;66(10):1393-7. Available http://www.ncbi.nlm.nih.gov/pubmed/17613555\%5Cnhttp://www.pubmedcentral.nih.gov/articlere nder.fcgi?artid=PMC1994295

70. Heldmann F, Dybowski F, Saracbasi-Zender E, Fendler C, Braun J. Update on biologic therapy in the management of axial spondyloarthritis. Curr Rheumatol Rep. 2010;12(5):325-31.

71. Coates LC, Cawkwell LS, Ng NWF, Bennett AN, Bryer DJ, Fraser AD, et al. Real life experience confirms sustained response to long-term biologics and switching in ankylosing spondylitis. Rheumatology. 2008;47(6):897-900.

72. Baraliakos X, Listing J, Rudwaleit M, Brandt J, Sieper J, Braun J. Radiographic progression in patients with ankylosing spondylitis after 2 years of treatment with the tumour necrosis factor alpha antibody infliximab. Ann Rheum Dis. 2005;64(10):1462-6.

73. Braun J, Brandt J, Listing J, Zink A, Alten R, Burmester G, et al. Two year maintenance of efficacy and safety of infliximab in the treatment of ankylosing spondylitis. Vol. 64, Annals of the rheumatic diseases. 2005.

74. Van Der Heijde D, Landewé R, Baraliakos X, Houben H, Van Tubergen A, Williamson P, et al. Radiographic findings following two years of infliximab therapy in patients with ankylosing spondylitis. Arthritis Rheum. 2008;58(10):3063-70.

75. Van Der Heijde D, Landewé R, Einstein S, Ory P, Vosse D, Ni L, et al. Radiographic progression of ankylosing spondylitis after up to two years of treatment with etanercept. Arthritis Rheum. 2008;58(5):1324-31.

76. Baraliakos X, Haibel H, Listing J, Sieper J, Braun J. Continuous long-term anti-TNF therapy does not lead to an increase in the rate of new bone formation over 8 years in patients with ankylosing spondylitis. Ann Rheum Dis [Internet]. 2014;73(4):710-5. Available from: http://www.ncbi.nlm.nih.gov/pubmed/23505240

77. Baraliakos X, Listing J, Fritz C, Haibel H, Alten R, Burmester GR, et al. Persistent clinical efficacy and safety of infliximab in ankylosing spondylitis after 8 years-early clinical response predicts long-term outcome. Rheumatology. 2011;50(9):1690-9.

78. Haroon N, Inman RD, Learch TJ, Weisman MH, Lee M, Rahbar MH, et al. The impact of tumor necrosis factor?? inhibitors on radiographic progression in ankylosing spondylitis. Arthritis Rheum. 2013;65(10):2645-54.

79. Machado P. Anti-tumor necrosis factor and new bone formation in ankylosing spondylitis: the controversy continues. Arthritis Rheum [Internet]. 2013;65(10):2537-40. Available from: http://www.ncbi.nlm.nih.gov/pubmed/23818040

80. Maas F, Arends S, Brouwer E, Essers I, van der Veer E, Efde M, et al. Reduction in Spinal Radiographic Progression in Ankylosing Spondylitis Patients Receiving Prolonged Treatment With Tumor Necrosis Factor Inhibitors. Arthritis Care Res (Hoboken) [Internet]. 2017 Jul 1 [cited 2017 Sep 18];69(7):1011-9. Available from: http://onlinelibrary.wiley.com/doi/10.1002/acr.23097/pdf

81. *Molnar C, Scherer A, Baraliakos X, De Hooge M, Micheroli R, Exer P, et al. Clinical and epidemiological research TNF blockers inhibit spinal radiographic progression in ankylosing spondylitis by reducing disease activity: results from the Swiss Clinical Quality Management 
cohort. Ann Rheum Dis [Internet]. 2017 [cited 2017 Oct 2];0:1-7. Available from: http://ard.bmj.com/content/annrheumdis/early/2017/09/22/annrheumdis-2017-211544.full.pdf

*Seminal study demonstrating that anti-TNF may have a role in inihibiting spinal radiographic progression

82. van der Heijde D, Baraliakos X, Hermann K-GA, Landewé RBM, Machado PM, Maksymowych $\mathrm{WP}$, et al. Limited radiographic progression and sustained reductions in MRI inflammation in patients with axial spondyloarthritis: 4-year imaging outcomes from the RAPID-axSpA phase III randomised trial. Ann Rheum Dis [Internet]. 2018 Jan 17 [cited 2018 Feb 22];annrheumdis-2017212377. Available from: http://www.ncbi.nlm.nih.gov/pubmed/29343510

83. Secukinumab Demonstrates Low Radiographic Progression and Sustained Efficacy through 4 Years in Patients with Active Ankylosing Spondylitis - ACR Meeting Abstracts [Internet]. [cited 2018 Feb 22]. Available from: http://acrabstracts.org/abstract/secukinumab-demonstrates-lowradiographic-progression-and-sustained-efficacy-through-4-years-in-patients-with-activeankylosing-spondylitis/

84. Tan AL, Marzo-Ortega H, O'Connor P, Fraser A, Emery P, McGonagle D. Efficacy of anakinra in active ankylosing spondylitis: a clinical and magnetic resonance imaging study. Ann Rheum Dis [Internet]. 2004 Sep [cited 2017 Sep 18];63(9):1041-5. Available from: http://www.ncbi.nlm.nih.gov/pubmed/15066864

85. Haibel H, Rudwaleit M, Listing J, Sieper J. Open label trial of anakinra in active ankylosing spondylitis over 24 weeks. Ann Rheum Dis [Internet]. 2005 [cited 2017 Sep 18];64:296-8. Available from: https://www.ncbi.nlm.nih.gov/pmc/articles/PMC1755331/pdf/v064p00296.pdf

86. Song I-H, Heldmann F, Rudwaleit M, Haibel H, Weiss A, Braun J, et al. Treatment of active ankylosing spondylitis with abatacept: an open-label, 24-week pilot study. Ann Rheum Dis [Internet]. 2011 Jun [cited 2017 Sep 18];70(6):1108-10. Available from: http://www.ncbi.nlm.nih.gov/pubmed/21415053

87. Song I-H, Heldmann F, Rudwaleit M, Listing J, Appel H, Braun J, et al. Different response to rituximab in tumor necrosis factor blocker-naive patients with active ankylosing spondylitis and in patients in whom tumor necrosis factor blockers have failed: a twenty-four-week clinical trial. Arthritis Rheum [Internet]. 2010 May [cited 2017 Sep 18];62(5):1290-7. Available from: http://www.ncbi.nlm.nih.gov/pubmed/20461780

88. Song I-H, Heldmann F, Rudwaleit M, Listing J, Appel H, Haug-Rost I, et al. One-year follow-up of ankylosing spondylitis patients responding to rituximab treatment and re-treated in case of a flare. Ann Rheum Dis [Internet]. 2013 Feb [cited 2017 Sep 19];72(2):305-6. Available from: http://ard.bmj.com/lookup/doi/10.1136/annrheumdis-2012-201926

89. Sieper J, Porter-Brown B, Thompson L, Harari O, Dougados M. Assessment of short-term symptomatic efficacy of tocilizumab in ankylosing spondylitis: results of randomised, placebocontrolled trials. Ann Rheum Dis [Internet]. 2014 Jan 1 [cited 2017 Sep 21];73(1):95-100. Available from: http://www.ncbi.nlm.nih.gov/pubmed/23765873

90. Pathan E, Abraham S, Van Rossen E, Withrington R, Keat A, Charles PJ, et al. Efficacy and safety of apremilast, an oral phosphodiesterase 4 inhibitor, in ankylosing spondylitis. Ann Rheum Dis [Internet]. 2013;72(9):1475-80. Available from: http://www.ncbi.nlm.nih.gov/pubmed/22984171

91. Burmester GR, Blanco R, Charles-Schoeman C, Wollenhaupt J, Zerbini C, Benda B, et al. Tofacitinib (CP-690,550) in combination with methotrexate in patients with active rheumatoid arthritis with an inadequate response to tumour necrosis factor inhibitors: a randomised phase 3 trial. Lancet. 2013;381(9865):451-60.

92. Van Der Heijde D, Deodhar A, Wei JC, Drescher E, Fleishaker D, Hendrikx T, et al. Tofacitinib in patients with ankylosing spondylitis: a phase II, 16-week, randomised, placebo- controlled, dose$\begin{array}{llllll}\text { ranging study. } & \text { [cited } 2017 \text { Sep } & \text { 21]; Available from: }\end{array}$ http://ard.bmj.com/content/annrheumdis/76/8/1340.full.pdf

93. Kay J, Schoels MM, Dörner T, Emery P, Kvien TK, Smolen JS, et al. Consensus-based recommendations for the use of biosimilars to treat rheumatological diseases on behalf of the Task 
Force on the Use of Biosimilars to Treat Rheumatological Diseases. Ann Rheum Dis [Internet]. 2017 [cited 2017 Oct 2];0(10):1-10. Available [rom: http://ard.bmj.com/content/annrheumdis/early/2017/09/02/annrheumdis-2017-211937.full.pdf

94. Giardina AR, Ferrante A, Ciccia F, Impastato R, Miceli MC, Principato A, et al. A 2-year comparative open label randomized study of efficacy and safety of etanercept and infliximab in patients with ankylosing spondylitis. Rheumatol Int [Internet]. 2010 Sep 23 [cited 2017 Oct 8];30(11):1437-40. Available from: http://link.springer.com/10.1007/s00296-009-1157-3

95. Braun J, Baraliakos X, Listing J, Sieper J. Decreased incidence of anterior uveitis in patients with ankylosing spondylitis treated with the anti-tumor necrosis factor agents infliximab and etanercept. Arthritis Rheum [Internet]. 2005 Aug [cited 2017 Sep 18];52(8):2447-51. Available from: http://www.ncbi.nlm.nih.gov/pubmed/16052578

96. van Denderen JC, Visman IM, Nurmohamed MT, Suttorp-Schulten MSA, van der Horst-Bruinsma IE. Adalimumab significantly reduces the recurrence rate of anterior uveitis in patients with ankylosing spondylitis. J Rheumatol [Internet]. 2014 Sep [cited 2017 Sep 18];41(9):1843-8. Available from: http://www.ncbi.nlm.nih.gov/pubmed/25086071

97. Sieper J, Koenig A, Baumgartner S, Wishneski C, Foehl J, Vlahos B, et al. Analysis of uveitis rates across all etanercept ankylosing spondylitis clinical trials. Ann Rheum Dis [Internet]. 2010 Jan 1 [cited 2017 Sep 18];69(1):226-9. Available from: http://www.ncbi.nlm.nih.gov/pubmed/19465402

98. Rudwaleit M, Rosenbaum JT, Landewé R, Marzo-Ortega H, Sieper J, van der Heijde D, et al. Observed Incidence of Uveitis Following Certolizumab Pegol Treatment in Patients With Axial Spondyloarthritis. Arthritis Care Res (Hoboken) [Internet]. 2016 Jun [cited 2017 Sep 18];68(6):838-44. Available from: http://www.ncbi.nlm.nih.gov/pubmed/26815944

99. Foster CS, Tufail F, Waheed NK, Chu D, Miserocchi E, Baltatzis S, et al. Efficacy of Etanercept in Preventing Relapse of Uveitis Controlled by Methotrexate. Arch Ophthalmol [Internet]. 2003 $\begin{array}{llllll}\text { Apr } & 1 & \text { [cited } 2017 \quad \text { Sep } & 18] ; 121(4): 437 . & \text { Available from: }\end{array}$ http://www.ncbi.nlm.nih.gov/pubmed/12695239

100. Gossec L, Smolen JS, Ramiro S, de Wit M, Cutolo M, Dougados M, et al. European League Against Rheumatism (EULAR) recommendations for the management of psoriatic arthritis with pharmacological therapies: 2015 update. Ann Rheum Dis [Internet]. 2016 Mar 1 [cited 2017 Sep 18];75(3):499-510. Available from: http://www.ncbi.nlm.nih.gov/pubmed/26644232

101. Song I-H, Appel H, Haibel H, Loddenkemper C, Braun J, Sieper J, et al. New onset of Crohn's disease during treatment of active ankylosing spondylitis with etanercept. J Rheumatol [Internet]. 2008 Mar 1 [cited 2017 Sep 18];35(3):532-6. Available from: http://www.ncbi.nlm.nih.gov/pubmed/18203308

102. Cantini F, Niccoli L, Goletti D. Adalimumab, etanercept, infliximab, and the risk of tuberculosis: data from clinical trials, national registries, and postmarketing surveillance. J Rheumatol Suppl [Internet]. 2014 May [cited 2017 Sep 18];91:47-55. Available from: http://www.ncbi.nlm.nih.gov/pubmed/24789000

103. Hueber W, Sands BE, Lewitzky S, Vandemeulebroecke M, Reinisch W, Higgins PDR, et al. Secukinumab, a human anti-IL-17A monoclonal antibody, for moderate to severe Crohn's disease: unexpected results of a randomised, double-blind placebo-controlled trial. Gut [Internet]. 2012 Dec [cited $2017 \quad$ Sep 18];61(12):1693-700. Available from: http://www.ncbi.nlm.nih.gov/pubmed/22595313 